\title{
Human Education And Educational Issues For Society And Economy - Case In Emerging Markets Including Vietnam
}

\author{
*Thuy Dung Thi Vu , Dalat University, Vietnam \\ Le Thi Thanh Huong, Dai Nam University, Vietnam \\ Dinh Tran Ngoc Huy , Banking University HCMC, Ho Chi Minh city Vietnam - International University of \\ Japan, Japan \\ Le Ngoc Nuong, Thai Nguyen University of Economics and Business Administration (TUEBA), Vietnam \\ Ngo Thi Huyen Trang, Thai Nguyen University of Economics and Business Administration (TUEBA), \\ Vietnam \\ Nguyen Ngoc Thach, Banking University HCMC, Ho Chi Minh city, Vietnam
}

\begin{abstract}
Human education in Vietnam for society and economy has been paid much attention in recent years. By using historical analysis, combined with dialectical materialism method, this study aims to identify and analyze what factors affect human education in Vietnam society, for socio-economic development. This paper uses a combination of qualitative analysis, historical and dialectical materialism methods to analyze and give out recommendations.

Therefore, there are many factors that affect Vietnam human education including but not limited to: Western culture and education, Asian or Easter culture, Buddhism, Confucianism, Ho Chi Minh ideology, etc. We will explore their values in educating people in Vietnam society in the globalization and integration era. Last but not least, we will suggest some opinions on maintaing good traditional values and perspectives on educational issues for socio-economic development in an emerging market like Vietnam. Our recommendations can be applied in other emerging markets if suitable.
\end{abstract}

Keywords: human education, educational issues, Vietnam, socio-economic development, culture.

Received: 04.12.2020 Accepted: 19.01.2021 $\quad$ Published: 03.02.2021

\section{Introduction}

Nowadays, human education for a better society and economy is becoming one of foundation issues for socio-economic development and sustainability.

We need to break this topic into components that affect human education, then we can discuss educational issues for society and economy in emerging markets such as Vietnam.

We organize this study with introduction, research questions, literature review, methodology, main results, then discussion and conclusion.

Research questions:

Question 1: What are factors that affect human education in emerging markets such as Vietnam?

Question 2: What are educational issues and how these factors affect human educational issues for socio-economic development?

Ozturk (2001) said that no country can achieve sustainable economic development without substantial investment in human capital. Education enriches people's understanding of themselves and world. It improves the quality of their lives and leads to broad social benefits to individuals and society. Education raises people's productivity and creativity and promotes entrepreneurship and technological advances.

\section{Literature review}

Thuy, V.T.B (2012) stated that Ho Chi Minh Ideology of " growing humans" is the system of viewpoints on training, educating humans in order to serve the cause of building and protecting the nation. "Growing humans" is the primary strategy of the Vietnamese Revolution, which not only meets the requirements of the Revolution but also prepares for the future."Growing humans" is creating Vietnamese people developing their whole virtues, of which morality is the foundation. "Growing humans" is the permanent revolutionary cause associated with the strategy and policy on socio economic development. Ho Chi Minh Ideology of "growing humans" is our nation's precious spiritual asset. Applying Ho Chi Minh Ideology wisely, The Party and the State have introduced the strategy to develop Vietnamese people in the period of accelerated industrialization and modernization.It is the Party's general policy,measure to build, 
perfect the Vietnamese 's personalities to meet the requirement on the development of the country in the new age.

Usman and Adeyinka (2019) said there is positive and significant relationship between GDP and government expenditure on education, expenditure on health and school enrollment in the ECOWAS counties, the study concludes that human capital development has an effect on economic growth in the ECOWAS region,the study is very relevant to the post-2015 Sustainable Development Goals agendas for two fundamental reasons: (a) Exclusive development is a critical policy syndrome in ECOWAS region where human capital development is a key to attain the SDGs extreme poverty target despite enjoying more than two decades of growth resurgence in some member states. (b) Growth in the region can primarily be driven by high human capital with the population of member countries expected to double in about 30 years, high investment on education and health for inclusive development is very welcome.

Last but not least, Minh and Valdez (2019) analyzed the political ideologies reflected in the selected speeches of Ho Chi Minh and their implication to the thinking of Vietnamese youth. Findings of the analysis revealed that Ho Chi Minh's selected speeches vividly exhibited the aspects of his political ideologies as expressed in his ideological strategy on continuous proletarian revolution specifically on national liberation manifested through independence and unity; on national independence and unity expressed through democracy, freedom,welfare and happiness; and on socialism as one of his ideologies' major creative points. Moreover, the manifestations of the themes of patriotism, humanism, inner peace and moral philosophy are also evident in the literary works. And Hien (2020) mentioned that the revolutionary history of Vietnam was noted in August Revolution, creating a fundamental turning point in the upward development of the nation and people of Vietnam by an era of independence, freedom and socialism. Finally, Dieu, T.T. (2020) pointed that focuses on the case of Vietnam by analysing Ho Chi Minh's ideology. $\mathrm{He}$ is the initiator and builder of Vietnamese nation known as the ideology on great unity which continues to be expressed from theory to practice. Great national unity is both the goal and the top task of the revolution which may be seen thoroughly in all paths, guidelines and policies of the Party during the Party Congresses. This article further discusses the basis for the formulation of the national unity based on Ho Chi Minh's ideology, explain why Ho Chi Minh can solve the national-class relationship, and draw out the implication for Vietnam in the stage of current development.

\section{METHODOLOGY}

\section{Method and data}

The method used in this research is qualitative analysis and explanatory research. The analysis process was carried out by using historical information and with historical and dialectical materialism methods.

\section{RESULTS}

\subsection{Findings on roles of Budihsm and Confucianism in educating people}

\begin{tabular}{|c|c|c|}
\hline & Buddhism ideology & Confucianism \\
\hline Benefits & $\begin{array}{l}\text { In-depth research and assessment } \\
\text { of the limitations as well as } \\
\text { progress and humanitarianism of } \\
\text { Buddhism help us to better } \\
\text { understand people's psychology } \\
\text { and thereby find a way to guide } \\
\text { them with a main personality. } \\
\text { right. To follow the religion to do } \\
\text { good to avoid evil, to form a better } \\
\text { human personality, not to become } \\
\text { superstitious, to worship, to go to } \\
\text { fields, to adversely affect the } \\
\text { health of beliefs of the masses. }\end{array}$ & $\begin{array}{l}\text { Confucianism was partly } \\
\text { involved in shaping the spiritual } \\
\text { appearance of the nation and in } \\
\text { the making of the national } \\
\text { culture, so it is necessary to } \\
\text { study Confucianism also affects } \\
\text { the culture and social values. }\end{array}$ \\
\hline Affect socio-economy & $\begin{array}{l}\text { The outstanding feature of } \\
\text { Buddhist teachings is that it is } \\
\text { truly close to, suitable for all walks } \\
\text { of life. Because, man is the object of } \\
\text { Buddhism education, the purpose } \\
\text { of Buddhist education is to direct } \\
\text { people to true happiness, come to } \\
\text { see the true value of present life. }\end{array}$ & $\begin{array}{l}\text { Connected with the need to } \\
\text { build and organize the central } \\
\text { feudal state apparatus was } \\
\text { strong and the need to } \\
\text { consolidate the stable order of } \\
\text { feudal society. }\end{array}$ \\
\hline
\end{tabular}




\begin{tabular}{|c|c|c|}
\hline & $\begin{array}{l}\text { Therefore, the Buddhist scriptures } \\
\text { have a very high humanistic } \\
\text { educational thought: "When } \\
\text { honesty towards people describes } \\
\text { the discovery, illuminates many } \\
\text { feelings of human legitimate } \\
\text { aspirations, helps people } \\
\text { understand more about Human, } \\
\text { about life to love, cherish, it is } \\
\text { human ". }\end{array}$ & \\
\hline Affect human education & $\begin{array}{l}\text { Buddhism has brought a } \\
\text { peacefulness before the crisis of } \\
\text { human soul and called to return to } \\
\text { real life, very real to assume the } \\
\text { responsibility of life, so Buddhist } \\
\text { education is: "One Such an } \\
\text { education will surely create the } \\
\text { models of ownership, living for the } \\
\text { benefit of oneself and for the } \\
\text { society, breaking all the bondage } \\
\text { inside and outside ". } \\
\text { Man is self-mastering with his } \\
\text { mind, intellectually, not enslaved } \\
\text { by any object situation, not } \\
\text { dominated by desire or craving. } \\
\text { Why? Craving is the source of all } \\
\text { ignorance, ignorance, and is the } \\
\text { beginning of suffering; do not } \\
\text { mistakenly think that the } \\
\text { attainment of satisfaction in desire } \\
\text { is happiness. That happiness is just } \\
\text { the beginning of suffering, has } \\
\text { implicit suffering. Therefore, } \\
\text { Buddhist education teaches us to } \\
\text { recognize a source of true } \\
\text { happiness, a moral life with self- } \\
\text { control: "Be your own refuge", that } \\
\text { is the value of human education. }\end{array}$ & $\begin{array}{l}\text { In Confucianism, a great deal of } \\
\text { emphasis was placed on } \\
\text { teaching the religion of being } \\
\text { human. It must be said that the } \\
\text { religion of being a Confucius } \\
\text { teaches is humanism in feudal } \\
\text { society. We all know that in a } \\
\text { caste society the principles for } \\
\text { assessing human behavior, } \\
\text { human dignity in relation to } \\
\text { others and in relations with the } \\
\text { state, the country ... are classy } \\
\text { and historical. } \\
\text { Confucius teaching the word } \\
\text { Nhan to his students is not } \\
\text { always the same, but carefully, } \\
\text { the essence of the word Nhan is } \\
\text { compassion for people and it is } \\
\text { also Confucius who says "For } \\
\text { people as for me, not to do with } \\
\text { people. things I don't want } \\
\text { anyone to do with me. } \\
\text { Moreover, what we want to } \\
\text { establish for ourselves must be } \\
\text { established for people, what we } \\
\text { want to achieve must be done to } \\
\text { achieve, we must help people } \\
\text { become better without making } \\
\text { people worse "essay)" } \\
\text { Meaning "Is the right thing. } \\
\text { good road, right thing. }\end{array}$ \\
\hline
\end{tabular}

\subsection{Findings on Western culture , K. Marx and Ho Chi Minh ideology affecting human education}

\begin{tabular}{|c|c|c|}
\hline & $\begin{array}{l}\text { Western culture and } \\
\text { K.Marx ideology }\end{array}$ & $\begin{array}{l}\text { Ho Chi Minh ideology and } \\
\text { values }\end{array}$ \\
\hline Benefits for socio-economic & $\begin{array}{l}\text { Good education will bring } \\
\text { good employment for } \\
\text { people and workers in } \\
\text { between developing } \\
\text { markets and developed } \\
\text { countries. } \\
\text { Many new factors have emerged } \\
\text { in income distribution through } \\
\text { the formation and development } \\
\text { of the middle class including } \\
\text { civil servants, skilled workers } \\
\text { with decent living standards, }\end{array}$ & $\begin{array}{l}\text { In theory, Ho Chi Minh's } \\
\text { political ideology reflects } \\
\text { his views on the } \\
\text { organization and control of } \\
\text { the state apparatus within a } \\
\text { country and the state } \\
\text { relations among countries; } \\
\text { the activities of a class, a } \\
\text { political party, Black over } \\
\text { White background xi or a } \\
\text { social corporation aimed at } \\
\text { gaining or maintaining }\end{array}$ \\
\hline
\end{tabular}




\begin{tabular}{|c|c|c|}
\hline & $\begin{array}{l}\text { and part of the public. } \\
\text { Shareholders have shares, } \\
\text { shareholders in companies } \\
\text { become investors through } \\
\text { buying stocks, bonds, savings } \\
\text { certificates and earning } \\
\text { dividends on stocks, bonds and } \\
\text { interest rates on deposits ... in } \\
\text { private countries. development } \\
\text { version. Many developed } \\
\text { capitalist countries have } \\
\text { attained a high level of social } \\
\text { welfare. is always } \\
\text { Surplus value is } \\
\text { associated with the production } \\
\text { of goods, the operational } \\
\text { objectives of the producer, of } \\
\text { the enterprises in the } \\
\text { commodity production, even in } \\
\text { the modern market economy } \\
\text { must be the surplus value. }\end{array}$ & $\begin{array}{l}\text { control of the state } \\
\text { apparatus. Ho Chi Minh's } \\
\text { political thought is both a } \\
\text { science - state leadership, } \\
\text { human leadership, mastery } \\
\text { science, social architecture - } \\
\text { as well as an art, belonging } \\
\text { to proletarian ideology. } \\
\text { His very good viewpoints is that } \\
\text { the economy we build is a } \\
\text { socialist economy with modern } \\
\text { industry and agriculture, } \\
\text { advanced science and } \\
\text { technology. On the basis of the } \\
\text { increasingly developed socialist } \\
\text { economy, capitalist exploitation } \\
\text { has been gradually abolished, } \\
\text { the people's material and } \\
\text { cultural life is increasingly } \\
\text { improved. }\end{array}$ \\
\hline Affect Human education & $\begin{array}{l}\text { Trade openness bring many } \\
\text { educational opportunities } \\
\text { from Western countries to } \\
\text { Asian countries including } \\
\text { Vietnam, together with } \\
\text { trade and business } \\
\text { activities. }\end{array}$ & $\begin{array}{l}\text { Ho Chi Minh inherited and } \\
\text { absorbed the positive aspects of } \\
\text { Confucianism. He puts the } \\
\text { people on the first priority. }\end{array}$ \\
\hline
\end{tabular}

\section{DISCUSSION}

There are several human educational issues we need to discuss as follows:

- Accordingly, human consciousness, thought is explained by human existence itself.

- From Ho Chi Minh views on education: Fostering people with right ideas and high and beautiful emotions. Next, Improving people's knowledge, that is, referring to the educational function of culture. Those who advocate to raise the people of the people, first of all, the whole people must be determined to eliminate the "ignorance", to eliminate illiteracy, gradually improve their qualifications, "study to work, be a human, be an official", turning our country into a highly cultural country. Learning must go hand in hand with practice and practice. Learning everywhere at all times, to constantly improve political knowledge, expertise, cultivate Marxism-Leninism, from which to apply creatively in our country's circumstances.

- The socialist economy must be created on the basis of the regime of public ownership of the means of production. In the transition period, that economy still existed four main forms of ownership: "State ownership means that of the entire people. Ownership of the cooperative means the ownership of the working people's collective. Ownership of individual employees. A few means of production are owned by the capitalist ", of which" the state economy is a form of ownership by the entire people, it leads the national economy and the State must ensure its prosperous development. first ". Thus, Ho Chi Minh was the person who soon proposed the development of a multi-sector economic structure in the period of transition to socialism in our country.

Beside, Wang and Liu (2016) shows that in general, education human capital has a significant positive impact on economic growth. The positive impact of higher education on economic growth is especially significant, however, the primary education and secondary education does not have a significant impact on economic growth.

Kim et al (2019) stated the effect of education (health) on income tends to be greater (smaller) in countries with higher levels of development, greater (less) trade openness, less abundant natural resources, less corruption, higher levels of democracy, and a more homogeneous society.

Another issues is education for students in Vietnam still fill a gap between schools and workplace as we suggest below:

According to statistics at Thai Nguyen University in Vietnam, 9.74\% of graduates still have jobs that are not suitable for their major, so the University needs to continue to improve further in training programs as well 
as teaching and helping students. Members increase practice time and practice in order to have the best access in the first time when entering the work.

In addition to parallel professional learning, the University needs to promote activity programs to help students supplement and practice non-professional skills such as communication skills, public speaking skills. , group work skills ... Through the actual survey, quite a lot of students identified the need for additional training and soft skills. It helps students to be more confident in the job interview as well as an effective auxiliary tool for later work.

Moreover, to help graduate students have better ability to find jobs, the university also needs to connect with businesses in all fields, economic sectors and regions.

\section{Conclusion \\ Human education is affected by many perspectives: Buddhism philosophy, Confucianism, Western culture and K.Marx ideology and Ho Chi Minh views.}

Ho Chi Minh ideology is based on the theoretical ground of Marxism-Leninism, Ho Chi Minh's ideology, the viewpoint of the Communist Party of Vietnam on social leadership.

Minh and Valdez (2019) stated that Ideology is commonly understood as having a core thought that basically refers to a human being's ideals, beliefs, or philosophical views, and how man formulates those lessons into being of influence to his future. It is the creed by which every human being strives to live by. It is the casting mold by which man's character is forged and stamped. While it is very important for an individual's character to possess a uniqueness that distinguishes himself from others, it is equally important that man's character is shaped, or at the very least, inspired by people who have made their mark on this world: great leaders and people of remarkable influence who, even long after they are gone, their ideology will continue to impact society by virtue of inspiration. Ideologies leave a solid mark, those that are bequeathed to and embraced wholeheartedly by any individual, family, community, nation or state that wills itself to come out of its limited comfort and security, and out into the world that offers boundless opportunities for change.

His characters include independent thinking, self-control, creativity, and sharp critical thinking of Ho Chi Minh. He is a person with ambition, the ideal of deep love for the country. Bui Dinh Phong (2020) stated Ho Chi Minh ideological value is determined and recognized in many aspects, such as culture, morality, humanities, development whose cores are peace, national independence, democracy and social progress, looking forward the future as affirmed by the United Nations Educational, Scientific and Cultural Organization (UNESCO). These values arenot only inspiring and spreading around the world but are also a driving force contributing to the development of humanity and the encouragement of future generations. Applying Ho Chi Minh's political point of view in the current context is to rely on the strength of the entire people. People are the roots of nation. Applying and developing Ho Chi Minh's thought on great solidarity for the entire people, constantly taking care of building and developing human resources; fostering patriotism in combination with genuine international spirit; have a pure, indecent, indecent, indecent, and honest revolutionary lifestyle and morality, indifferent, free of corruption and other negative things; relying on the strength of the people, building and strengthening the block of great unity all people; creating conditions for people to fulfill their citizenship.

\section{References}

1. Dieu, T.T. (2020). Ho Chi Minh's Ideology on National Unity in Vietnam's Revolution, The Indonesian Journal of Southeast Asian Studies, 4(1). https://doi.org/10.22146/ikat.v4i1.56279

2. Dror, O. (2016). Establishing Hồ Chí Minh's Cult: Vietnamese Traditions and Their Transformations, The Journal of Asian Studies, 75(2): 433-466. DOI: https://doi.org/10.1017/S0021911815002041

3. Hien, L. Q. (2020). An Analysis of the Role of the President of Ho CHi Minh in Vietnam's Revolutionary History - An Insight from the 1945 August Revolution, Journal of Critical Reviews, 7(12).

4. Kim, D.H. (2019). Education, Health, And Economic Development, Macroeconomic Dynamics, 23(2): 837 - 869. DOI: https://doi.org/10.1017/S1365100517000050

5. Minh, N.T.H., \& Valdez, M.L.A. (2019). Ideologies Reflected in the Selected Speeches of Ho Chi Minh, International Journal on Studies in English Language and Literature, 7(4): 17-28.

6. Ozturk, I. (2001). The Role of Education in Economic Development: A Theoretical Perspective, SSRN Electronic Journal. DOI: 10.2139/ssrn.1137541

7. Phong, B.D. (2020). The Values of Ho Chi Minh thoughts from Its Pervasive Influence in the World. Communist Review. Retrieved

from:

https://www.tapchicongsan.org.vn/web/english/international/detail/-

Lasset publisher/ZeaSwtFItMgN/content/the-value-of-ho-chi-minh-s-thought-from-its-pervasiveinfluences-in-the-world (date access 23/1/2021). 
8. Thuy, V.T.B (2012). Ho Chi Minh Ideology Of “Growing Humans” And the Communist Party's Application In the Present Phase, UED Journal of Social Sciences, Humanities and Education, 2(2). https://doi.org/10.47393/jshe.v2i2.393

9. Tran Duong (2008), Ho Chi Minh genius predictor, Publisher Youth.

10. Truong Chinh (1991), President Ho Chi Minh and the Vietnamese revolution Nam, Information Theory Publishing House, Hanoi.

11. Usman, F.K., \& Adeyinka, O.B. (2019). Effect of Human Capital Development on Economic Growth of Ecowas Member States, Advances in Sciences and Humanities

, 5(1): $27-42$

12. V.I. Lenin (2005), Complete Works, Vol.33, National Political Publishing House, Hanoi.

13. Wang, Y., Lium, S. (2016). Education, Human Capital and Economic Growth: Empirical Research on 55 Countries and Regions (1960-2009), Theoretical Economics Letters, 06(02):347-355. DOI: $10.4236 /$ tel.2016.62039

14. William J. Duiker, "What is to be Done? Ho Chi Minh's Road Kach Mei”, Essays into Vietnamese Parts, K.W. Taylor and John Black over White background 233 K. Whitmore, eds. New York: Cornell University Southeast Asia Program, 1995. 